NASA Technical Memorandum 107504

AIAA-97-2872

\title{
Effects of Compression, Staging, and Braid Angle on Braided Rope Seal Performance
}

Bruce M. Steinetz

Lewis Research Center

Cleveland, Ohio

and

Michael L. Adams

Modern Technologies Corporation

Middleburg Heights, Ohio

Prepared for the

33rd Joint Propulsion Conference and Exhibit cosponsored by AIAA, ASME, SAE, and ASEE

Seattle, Washington, July 6-9, 1997

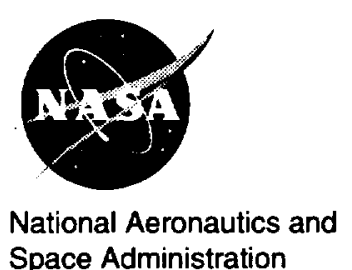

Space Administration 



\title{
EFFECTS OF COMPRESSION, STAGING, AND BRAID ANGLE ON BRAIDED ROPE SEAL PERFORMANCE
}

\author{
Bruce M. Steinetz* \\ National Aeronautics and Space Administration \\ Lewis Research Center \\ Cleveland, Ohio 44135 \\ Michael L. Adams $\dagger$ \\ Modern Technologies Corporation \\ Middleburg Heights, Ohio 44130
}

\begin{abstract}
$\underline{\text { Abstract }}$
Future turbine engines will be operating at increased temperatures to achieve more demanding efficiency and performance goals. In the highest temperature sections of the engine new material systems such as ceramics and intermetallics are being considered to withstand the harsh thermal environment. Components constructed of these low expansion-rate materials experience thermal strains and a resulting reduction of life when rigidly attached to high expansion-rate, superalloy support structures. Seals are being designed to both seal and to serve as compliant mounts allowing for relative thermal growths between high temperature but brittle primary structures and the surrounding support structures. Previous seal research yielded several braided rope seal designs which demonstrated the ability to both seal and serve as a compliant mount. The hybrid seal was constructed of an all-ceramic (alumina-silica) core overbraided with a superalloy wire sheath (cobalt based superalloy). The all ceramic seal was constructed of an all-ceramic (aluminasilica) core overbraided with multiple ceramic (aluminasilica) sheath layers.
\end{abstract}

Program goals for braided rope seals are to improve flow resistance and/or seal resilience. To that end, the current report studies the test results of: baseline and modified hybrid seals; two stage hybrid and two stage allceramic seal configurations; and single stage hybrid and single stage all-ceramic seal configurations for a range of seal crush conditions. Hybrid seal modifications include increasing the sheath braid angle and core coverage. For the same percent seal cross-sectional crush, results show that increasing the hybrid seal braid angle increased seal stiffness and seal unit load, resulting in flows approximately one third of the baseline hybrid seal flows. For both hybrid and all-ceramic seals, two stage seal

*Senior Research Engineer, Mechanical Components Branch, Member AIAA.

†Research Engineer, Member AIAA. configurations significantly outperformed single stage configurations. Two stage seal flows were at least 30 percent less than the single stage seal flows for the same seal crush. Furthermore, test results of single stage seals indicate that for both all-ceramic and hybrid seals, a specific seal crush condition exists at which minimum flows are achieved (i.e., increasing seal crush beyond a certain point does not result in better flow performance). Flow results are presented for a range of pressures and temperatures from ambient to $1300^{\circ} \mathrm{F}$, before and after scrubbing. Compression tests results show that for both all-ceramic and hybrid seals, seal preload and stiffness increase with seal crush, but residual seal interference remains constant.

\section{Introduction}

High temperature compliant seals are required in modern aerospace propulsion systems to enable the system to meet operational and cycle efficiency goals. Seals are required to operate hot at temperatures from 1500 to $2000+{ }^{\circ} \mathrm{F}$, have low leakage, exhibit resilience with cycling to maintain a good seal, resist scrubbing damage, seal complex geometries, and support structural loads. Compliant seals are required to seal turbine vane/shroud interfaces in advanced engines where the turbine vane is made of advanced materials (ceramic matrix composites, intermetallics, etc.) operating at temperatures to $2000^{\circ} \mathrm{F}$. Compliant seals are also required to seal structural interfaces between adjoining engine panels of 2-dimensional nozzles, that are being considered for the High Speed Civil Transport, the X-33 single-stage-toorbit demonstrator, and advanced fighter engines. Furthermore compliant rope seals are being considered as a potential seal in the Space Shuttle solid rocket booster nozzle joints to serve as a flame barrier to protect the more positive silicone seal.

Copyright $\Theta$ by the American Institute of Aeronautics and Astronautics, Inc. No copyright is asserted in the United States under Title 17, U.S. Code. The U.S. Government has a royalty-free license to exercise all rights under the copyright claimed herein for Governmental Purposes. All other rights are reserved by the copyright owner. 


\section{Background}

Rope packings can be traced back to the early days of the industrial revolution to seal stuffing boxes and valves to prevent excessive leakage. An excellent summary of types of rope seal packings is given in Mathews and McKillop.' As engine temperatures have continued to rise novel adaptation of these seal packings were required to meet modern turbine engine and hypersonic engine requirements. NASA embarked on a program to develop high temperature $\left(\geq 1500^{\circ} \mathrm{F}\right.$ ), high pressure (up to $100 \mathrm{psi}$ ), flexible seals to meet aggressive sealing goals of ramjet/scramjet engines considered for future hypersonic vehicles (e.g., the National Aerospace Plane, NASP). The braided all-ceramic and hybrid seals were developed to operate hot, maintain resiliency and resist scrubbing damage over the life of the hypersonic engines. Steinetz et al. ${ }^{2}$ reports on the durability and flow resistance of both seals at temperatures up to $1500^{\circ} \mathrm{F}$. The all-ceramic seal survived about half- and the hybrid braided rope seal survived the full-sliding duty cycle anticipated for the hypersonic engine. The duty cycle in this previous application far exceeded that required herein. Flow models for predicting leakage flow through these porous structures are reported in Cai et al.$^{3,4}$ and Mutharasan et al. ${ }^{5}$ Steinetz et al. ${ }^{6}$ demonstrated the feasibility of applying first generation small diameter (1/16 in.) all-ceramic seals for an industrial application and hybrid seals to seal the interface between a nickel aluminide turbine vane and supporting structure.

The objective of the current study is to extend the previous work by evaluating:

+ effects of braid angle on hybrid seal stiffness and leakage, flow

+ effects of two stage vs. single stage seals on seal

+ effects of increasing seal preload (percent crush); pressure drop; temperature; and hot scrubbing on both allceramic and hybrid seal flow and durability performance.

Where applicable, reference will be made to two current applications of the small diameter seals namely: a high pressure and a low pressure turbine vane seal.

GE High Pressure Turbine Vane Seal.-In the high pressure vane seal application, a seal is designed to serve as a seal and a compliant mount allowing relative thermal growth between the high temperature, low-expansion rate primary structure and a higher expansion rate structural support preventing excessive thermal strains and stresses. Two seals were examined for this study. The first allceramic seal consists of a tightly packed ceramic core overbraided with a ceramic sheath for low-leakage, low scrubbing environments. The second hybrid seal consists of a tightly packed ceramic core overbraided with a superalloy wire sheath (two different braid angles), and was tested as an abrasion-resistant alternative. GE successfully applied the $1 / 16$ in. diameter hybrid seal to seal the first stage turning vanes of an advanced demonstrator engine. ${ }^{6}$

Pratt \& Whitney Low Pressure Turbine Vane Seal.Based on the above GE success others are now considering the $1 / 8$ in. diameter hybrid seal to seal larger turning vanes in the low pressure turbine where temperatures are lower but durability is more of a concern. Pratt \& Whitney originally had planned to seal these interfaces with a braided all-ceramic seal construction. Engine testing has revealed that the ceramic seals will not meet the durability goals and have the potential for increasing cooling air leakage. More detail about application of the NASA hybrid seal is given in the Applications Section of this report.

\section{Test Apparatus}

\section{Flow Tests}

Flow experiments were performed on braided rope seals in a high temperature flow and durability test rig, shown schematically in Fig. 1. Test seals of $7.80 \pm 0.05$ in. length were mounted in the grooves of the piston, and the piston/seal assembly was inserted into the cylinder. The free ends of the seals were joined together in the groove by means of a short lap joint. Preload was applied to the seals through a known interference fit between the seal and the cylinder inner diameter, and the interference was varied (thus the preload was varied) by mounting stainless steel shims in the piston groove under the seal. During flow testing, hot pressurized air entered at the base of the cylinder and flowed to the test seal that sealed the annulus created by the cylinder and piston walls. For all tests the piston-to-cylinder radial gap was 0.007 in. The Inconel $\mathrm{X}-750$ test fixture is capable of flow and durability testing seals at temperatures between 70 and $1500^{\circ} \mathrm{F}$, pressures between 0 and $100 \mathrm{psig}$, and flows between 0 and 3.5 SCFM (standard cubic feet per minute).

At high temperatures, the durability of the test seals is investigated by reciprocating the piston within the stationary cylinder. Piston stroke movements of 0.3 in. were used in these tests to simulate relative thermal growths. Movement of the piston is guided by preloaded precision linear bearings.

Other basic hardware, heating systems, measurement techniques and probe accuracy for this test facility are all reported in detail by Steinetz et al. ${ }^{6}$ 
Thermal Growth.-During data collection, special care was taken to monitor the relative temperatures of the piston and the cylinder. The cylinder outer wall temperature and the piston inner wall temperature (the piston is hollow) were monitored, and flow data was collected only when the temperature differential between these surfaces was less than $40^{\circ} \mathrm{F}$. At operating conditions, a $40^{\circ}$ temperature differential results in no more than 0.0005 in. relative radial growth of the cylinder surface away from the piston surface.

A thermal growth differential also exists between the ceramic-based seal and the superalloy piston. As the piston circumferentially outgrows the seal, the seal ends move apart. In order to account for this, the seal free ends were joined together as a lap joint (Fig. 1). The lap joint prevents a free flow path from occurring. A lap joint of $3 / 32$ in. length minimum was used to prevent joint opening and to mitigate the effects of $1 / 16 \mathrm{in}$. in relative piston-toseal differential circumferential growth.

\section{Compression Tests}

Experiments were conducted in order to determine the preload behavior of seals with respect to the linear crush applied to the seals. Seal preload behavior was measured at room temperature during compressive loading using a precision linear slide compression test fixture (see schematic, Fig. 2). Seals were loaded into the grooved seal holder. The amount of seal compression was measured using a digital indicator monitoring the movement of the seal holder relative to the stationary plate. Average compressive load (and hence preload) was calculated by dividing the measured compressive force during loading by the contact area left on the pressure sensitive film, explained below.

A pressure sensitive film was mounted on the stationary plate such that the seal would contact only the film when the seal holder/moving plate assembly was moved into preload contact. The film develops under compressive loading, therefore the seal leaves a "footprint" after it has been crushed against the stationary plate. The pressure sensitive film begins to develop color under compressive loads greater than or equal to $28 \mathrm{psi}$, and the shade of the developed film becomes darker as the load is increased. At seal contact pressures greater than or equal to $100 \mathrm{psi}$, the developed color is dark enough to reliably measure the dimensions of the contact area. Contact width was measured using a dial vernier in several locations along the $1.0,2.0$, or $4.0( \pm 0.01)$ in. long specimen length. Seals with high stiffness required shorter specimen lengths, i.e., 1.0 and 2.0 in., in order to keep load data within the range of the test fixture load cells. Variations in contact width measurements were minimized by averaging multiple measurements.

In order to determine the accuracy of the width and length measurements, experiments were performed using the compression test fixture in which a rigid object of known width and length was compressed against pressure sensitive film samples. For applied loads of $100 \mathrm{psi}$ and greater, measured footprint widths and lengths on the film were within \pm 0.001 in. of the actual width and length of the object. Overall accuracy of preload values (i.e., contact pressure) was calculated ${ }^{6,7}$ to be \pm 3.4 percent of the value.

\section{Seal Specimens}

Two categories of rope seals were examined: allceramic seals and hybrid seals. The all-ceramic rope seal consists of a dense uniaxial core of ceramic fibers overbraided with a 2-layer ceramic fiber sheath. The ceramic fibers (Nextel 550) can operate to $2000{ }^{\circ} \mathrm{F}$ continuously $\left(2200^{\circ} \mathrm{F}\right.$ short term), are nonreactive, and resist abrasion ${ }^{8}$ better than either the Nextel 312 of 440 fibers. Small, $3.2 \times 10^{-4}$ in. $(8 \mu \mathrm{m})$ Nextel 550 fibers are selected for both the core and the sheath to minimize leakage through the seal and between the sheath and adjacent surfaces. Table 1 gives details of the seal sheath and core construction as well as information on material compositions.

Hybrid rope seals consist of a dense uniaxial core of Nextel 550 fibers overbraided with a single sheath layer composed of yarns of 0.0016 in. $(60 \mu \mathrm{m})$ Haynes 188 wire. Hybrid seals are selected for applications in which the seal must resist scrubbing damage against rough surfaces and resist potential damage due to acoustically induced fretting at $1500+{ }^{\circ} \mathrm{F}$. Fine diameter sheath wires are used to minimize sheath leakage. Hybrid rope seal specimens with braid angles of $46^{\circ}$ and $58^{\circ}$, shown in Fig. 3 (close-up photos), were examined separately in order to observe the effects of braid angle on seal stiffness and flow performance.

\section{Test Procedures}

\section{Flow Tests}

Prior to flow testing, seal specimens were mounted in the appropriate piston groove, and 0.002 in. thick Teflon film was wrapped around the piston/seal arrangement. The seal was then precompressed using a muffler clamp, and the piston/seal/Teflon film arrangement was inserted through a gradually tapered insertion tool. Thereafter the piston/seal/Teflon film arrangement was inserted into the cylinder, then retracted from the cylinder and the Teflon 
film removed. With the seal pre-worked in this manner, the piston/seal arrangement was reinserted into the cylinder. The above procedure was developed in order to minimize damage caused by the insertion process.

Seal flow data were collected before and after scrubbing ( 10 cycles of $0.3 \mathrm{in}$. linear stroke at $\left.1300^{\circ} \mathrm{F}\right)$ at temperatures of 70,1100 , and $1300^{\circ} \mathrm{F}$, and at pressures of $2,5,10,30,60,90$, and 100 psid. Downstream pressure for all tests was ambient pressure. Scrubbing cycles ${ }^{6}$ were applied to the seal specimens in order to examine the durability of the specimens. Flow tests were performed on single stage, 1/16 in. diameter all-ceramic rope seal specimens for linear seal compressions of $0.018,0.022$, 0.024 , and 0.026 in. Flow tests were performed on single stage, $1 / 16$ in. diameter hybrid seals (both braid angles) for linear seal compressions of $0.014,0.018$, and 0.021 in. Finally, flow tests were preformed for two stages of allceramic seals at a linear seal compression of 0.018 in., and for two stages of high braid angle hybrid seals at a linear seal compression of 0.014 in. In two-stage flow experiments, each seal stage was mounted in its own seal groove. Lap joints for the two stage seals were clocked at $180^{\circ}$ relative to one another to minimize leakage. Repeat flow tests were performed only for the two stage allceramic seals.

\section{Compression Tests}

Compression tests were performed on all-ceramic and hybrid rope seals in order to determine the seal preloads corresponding to the linear seal crushes used in the flow experiments. A test procedure is described in detail by Steinetz et al. ${ }^{6}$ which accurately simulates the loading conditions in the flow test fixture and facilitates the calculation of the resultant seal preload from measured quantities. In the test procedure, multiple load cycles are applied to the seal before the preload data point is recorded in order to remove most of the permanent set (i.e., hysteresis) which accumulates with load cycling of the seal specimens. Most permanent set occurs within the first three to four load cycles. The procedure also accounts for both normal and frictional loads that the specimens will experience in the flow fixture. The compression test procedure was validated using overhang measurements collected in the flow fixture after the flow tests. After each test the amount that the seal extended radially out of the piston groove was measured. This measurement gages the seal's compression-set or conversely the retained seal interference (e.g., preload) when loaded into the cylinder. The seal overhang data agreed to within 0.001 in. to that expected from the last cycle compression data.

\section{Results and Discussion}

\section{Flow Results}

Table 2 summarizes all-ceramic seal and hybrid seal flow rates (last column) at $100 \mathrm{psi}$ and $1300^{\circ} \mathrm{F}$ (except as noted), after scrubbing. Of the single stage all-ceramic seal flow tests, the test with 0.022 in. of linear crush resulted in the best flow performance, better even than higher compression experiments. Seals in the higher compression experiments (i.e., 0.024 and 0.026 in. linear crush) flowed more than the 0.022 in crush seal because of sheath damage sustained during seal installation. The sheath damage was caused by the large interferences and the resulting high preloads and friction forces, even though great care was used in installing the seals. The best flow results overall for all-ceramic seals, however, were obtained with two seal stages at a linear crush of 0.018 in. The two stage flow results were approximately 40 percent of the one stage flow results for the same linear crush (i.e., $0.018 \mathrm{in}$.). The effects of seal compression and staging on seal flow for $1 / 16$ in. diameter all-ceramic seals can be seen graphically in Fig. 4 (flow data was collected at $10 \mathrm{psid}$ and $1300^{\circ} \mathrm{F}$, after scrubbing).

Two Stage Seal in Common Groove.-Preliminary, two stage flow tests were performed on $1 / 16$ in. diameter all-ceramic seals in which two seals were mounted in the same seal groove (the groove width was 0.135 in., wide enough to accommodate two 0.063 in. diameter seals sideby-side) at a linear crush of $0.022 \mathrm{in}$. Two seals in the same groove are an overall simpler design, requiring only one groove and not requiring a lap joint. The flow results from these tests (not charted herein) were comparable to single stage seal flows for the same crush, without significant improvement. These seals experienced extensive damage during installation due to lack of seal groove sidewall support.

Effects of Hybrid Braid Angle and Stages.-The best measured hybrid seal flow results were obtained with single stage, high braid angle (i.e., 56 ) hybrid seals, with 0.018 and 0.021 in. of linear seal crush. The effects of compression, braid angle and staging on 1/16 in. diameter hybrid seal flow can be seen graphically in Fig. 5 (flow data shown at $10 \mathrm{psid}$ and $1300^{\circ} \mathrm{F}$, after scrubbing). The seal compressed to 0.021 in. sustained some sheath damage during installation due to high preload and friction loads. As a result, flow data sets for the 0.018 and 0.021 in. crush flow tests were not significantly different, which implies that no net flow benefit is gained by compressing the high braid angle hybrid seal beyond 0.018 in. Higher braid 
angle seal flows were approximately $1 / 3$ the value of the lower braid angle seal flows for the same test conditions. This large flow reduction is due in part to the higher unit load and also due to higher sheath flow resistance of the tighter braid pattern (see Fig. 3).

Flow results for the two stage, high braid angle, hybrid seal flow test were approximately 70 percent the value of the corresponding single stage test $(0.014 \mathrm{in}$. seal crush for both flow tests). Higher seal crushes for two stages of hybrid seals were attempted, but installation could not be completed due to excessive installation loads.

Best case flow vs pressure data for the single stage flow tests are shown in Figs. 6 and 7 for all-ceramic and hybrid seals, respectively. Figure 6 presents flow versus pressure data for a single stage, 1/16 in. diameter allceramic seal with 0.022 in. linear compression, at pressures of 2 to $100 \mathrm{psid}$, and at three temperatures (70, 1100 , and $1300^{\circ} \mathrm{F}$ ). Figure 7 presents flow vs pressure data for a single stage, $1 / 16 \mathrm{in}$. diameter, high braid angle hybrid seal with $0.018 \mathrm{in}$. linear compression, at pressures of 2 to $100 \mathrm{psid}$, and at three temperatures $(70,1100$, and $1300^{\circ} \mathrm{F}$ ). Flow vs pressure data for the double stage flow tests are shown in Figs. 8 and 9 for all-ceramic and hybrid seals, respectively. Figure 8 presents flow versus pressure data for two stages of $1 / 16$ in. diameter all-ceramic seal with 0.018 in. linear compression, at pressures of 2 to $100 \mathrm{psid}$, and at three temperatures $\left(70,1100\right.$ and $\left.1300^{\circ} \mathrm{F}\right)$. Figure 9 presents flow vs pressure data for two stages of $1 / 16$ in. diameter hybrid seal with 0.014 in. linear compression, at pressures of 2 to $100 \mathrm{psid}$, and at three temperatures $\left(70,1100\right.$, and $\left.1300^{\circ} \mathrm{F}\right)$. In all of the above cases, flow behaves (approximately) as a linear function of pressure. Furthermore, the flow rates for all seals at elevated temperatures were lower than flow rates at room temperature. Gas viscosity increases with temperature, $\mu \alpha \mathrm{T}^{2 / 3}$, which suggests that flow will decrease with temperature.

Effect of Hot Scrubbing.-All-ceramic seal flow did not increase by more than 10 percent after scrubbing for tests with seal crushes of 0.018 and 0.022 in. Figure 10 shows a close-up view of the $1 / 16$ in. diameter, 0.022 in. crush, all-ceramic seal after 10 cycles of 0.3 in. scrubbing at $1300^{\circ} \mathrm{F}$. Some minor sheath fiber damage is present, more so than for the 0.018 in. seal crush condition previously reported by Steinetz et al. ${ }^{6}$ All-ceramic seal flow increase by 20 percent or less after scrubbing for tests with seal crushes of 0.024 and 0.026 in. Sheath fiber damage was more drastic for the 0.024 and 0.026 in. seal crush flow tests. Around most of the perimeter of the seals, core fibers could be clearly seen through sections of damaged sheath.

Hybrid seal flow improved slightly with hot scrubbing for the 0.014 and 0.018 in. seal crush conditions. For 0.014 in. of seal crush, seal flow improved by less than 8 percent after scrubbing; and for 0.018 in. of seal crush, seal flow improved by less than 5 percent after scrubbing. Figure 11 shows a close-up photo of the 1/16 in. diameter, 0.014 in. crush, hybrid seal after 10 cycles of 0.3 in. scrubbing at $1300^{\circ} \mathrm{F}$. The seal sheath was not damaged away from the lap joint (center of photo). The postscrubbing condition of the 0.018 in. crush hybrid seal was similar. Seal flow increased by less than 10 percent after scrubbing for the 0.021 in. seal compression condition. The 0.021 in. crush hybrid seal had sheath damage in four locations where approximately $0.5 \mathrm{in}$. long sections of the sheath had been removed. Some of this damage occurred during installation.

This report shows that dramatic improvements in braided rope seal flow can be obtained without sacrificing durability by increasing linear crush to an optimum condition ( 0.022 in. linear crush, all-ceramic seal; 0.018 in. linear crush, $56^{\circ}$ braid angle hybrid seal), modifying braid geometry and/or using two seal stages.

\section{Compression Results}

Table 2 summarizes all-ceramic seal and hybrid seal compression test results, including estimated preload, contact width and residual seal interference (residual interference is defined as the distance the seal will spring back while maintaining a seal load of at least $1 \mathrm{lb}$ per inch of seal). During a compression experiment, the seal sample is repeatedly subjected to the same linear crush. The footprint width of the last load cycle is used in conjunction with the measured force vs crush information in order to estimate the preload and residual interference which correspond to the linear crush value (Steinetz et al. ${ }^{6}$ ). Multiple load cycles are used in order to remove the majority of seal hysteresis before preload and residual interference are estimated. Figure 12 shows the force vs deflection characteristics for a $1 / 16$ in. diameter all-ceramic seal for a linear crush of 0.022 in. Figure 13 shows the force vs deflection characteristics for a $1 / 16 \mathrm{in}$. hybrid seal for a linear crush of 0.014 in.

For all seals tested (all-ceramic and hybrid seals), preload increased with linear crush. In the case of hybrid seals, preload increased significantly with the braid angle. Increasing the 1/16 in. diameter hybrid seal braid angle 
from $46^{\circ}$ to $58^{\circ}$ increased the preload by a factor of 6 , approximately. This implies that the $58^{\circ}$ braid angle hybrid seals are much stiffer than the $46^{\circ}$ braid angle hybrid seals.

Seal contact width also increased with linear crush. Hybrid seal braid angles, however, did not affect the seal contact width significantly. Compression experiments not only produce contact width information, but they also produce visual evidence of the nature of the seal footprints as well. After the pressure sensitive film develops under a preloaded seal, observations can be made regarding the quality and continuity of the seal contact with its mating surfaces. At all linear crushes reported herein, the allceramic seal and hybrid seal footprints were solid and continuous. This solid contact restricts flow between the walls and the seal, thus reducing overall seal leakage.

For all-ceramic seals, residual interference essentially remained constant at approximately 0.011 in. for linear crush values of 0.018 to 0.026 in. Likewise, residual interference remained constant for hybrid seals at approximately $0.006 \mathrm{in}$. for linear crush values of 0.014 and 0.018 in. Although residual interference remains fairly constant for each seal type, both all-ceramic and hybrid seals stiffen with increasing linear crush; therefore seals with a larger linear crush will lose seal load more rapidly than seals with a smaller linear crush during offloading within the range of the residual interference.

\section{Pratt \& Whitney Turbine Vane Seal Application}

Pratt \& Whitney is developing the F119 turbine engine to power the country's next generation premier fighter aircraft the F22. The high thrust output combined with its ability to sustain supersonic cruise without afterburner greatly increases the fighter's range and lethality.

The last stage turning vane of the F119 turbine engine requires seals around its perimeter (Fig. 14) to limit flow of fan cooling air past the turning vane/flowpath fairing interface and to prevent back flow of potentially damaging high temperature core air. The turning vane, nominally one foot long, straightens the core flow coming out of turbine engine before entering the afterburner. PW originally had planned to seal these interfaces with a braided all-ceramic seal construction. Key seal design conditions include sealing pressure differential across the seal of 50 psid. The maximum seal metal temperature is expected to be in the range of 1000 to $1200^{\circ} \mathrm{F}$.

Engine testing has revealed that the ceramic seals will not meet the durability goals and has the potential for increasing cooling air leakage. The exact cause of this problem is unclear but it may be attributed to limited abrasion resistance of the all-ceramic seal design or possible extrusion of the seal from the seal channel.

To help solve this problem, PW is evaluating a replacement hybrid seal from NASA (NTWHY-3, 1/8 in. diameter) that should reduce chances of extrusion due to its tougher, more abrasion resistant sheath. Seal compression upon installation is 0.025 in. to help accommodate manufacturing tolerances and differential vane-to-flowpath fairing thermal growths. PW is planning a full-scale engine test in the latter half of 1997 to qualify durability improvements of the hybrid seal.

\section{Summary and Conclusions}

As operating temperatures of advanced gas turbines continue to rise, designers face difficult challenges when implementing high temperature structural materials and seals in order to meet system performance goals. To maximize efficiency, coolant flows are being reduced to their practical minimum, facilitating a need for low-leakage seals made of temperature resistant superalloy and ceramic materials. Seals are being designed to both seal and serve as compliant mounts, allowing for relative thermal growths between high temperature but brittle primary structures and the surrounding support structures.

Flow and durability performance of all-ceramic and hybrid seals was measured for advanced gas turbine applications. Compression tests were performed in order to determine force vs deflection, preload vs linear seal crush, contact area and retained seal interference characteristics. Based on the tests discussed herein, the following observations are made:

1. Increasing linear seal crush (and thus seal preload) reduces seal leakage to a point. Increasing seal crush beyond this point results in seal damage which causes leakage to rise. Seal damage is caused by large preload and frictional forces (abrasion).

2. Optimum single stage flow results for $1 / 16$ in. diameter all-ceramic seals were obtained at 0.022 in. linear seal crush. Likewise, optimum single stage flow results for $1 / 16$ in. diameter, high braid angle hybrid seals were obtained at 0.018 in. linear seal crush.

3. For hybrid seals, increasing the sheath braid angle resulted in approximately 60 percent less seal leakage, higher seal stiffness and higher seal preload (approximately 6 times larger than lower braid angle hybrid seals). 
4. Two stages of all-ceramic seals at 0.018 in. seal crush exhibited approximately 60 percent less flow than one stage of all-ceramic seal at the same conditions. Two stages of hybrid seals at 0.014 in. seal crush exhibited approximately 30 percent less flow than one stage of hybrid seal at the same conditions. For the above twostage tests, each seal stage was mounted in its own seal groove.

\section{Acknowledgments}

The authors acknowledge the contributions of Mr. Tom Doeberling (NASA) for his assistance in seal installation and test support, and Mr. Jerome Katy (Pratt \& Whitney) for his consultation and testing of the seals in the F119 test engine.

\section{$\underline{\text { References }}$}

${ }^{1}$ Mathews, A., and McKillop, G.R. "Compression Packings," Machine Design Seals Reference Issue, Chapter 8, Penton Publishing, March, 1967.

${ }^{2}$ Steinetz, B.M., Kren, L.A., and Cai, Z., "High Temperature Flow and Sliding Durability Assessments of Hypersonic Engine Seals," NASA TP-3483, December, 1994.
${ }^{3}$ Cai, Z., Mutharasan, R., Ko, F., and Steinetz, B.M., "Development of Hypersonic Engine Seals: Flow Effects of Preload and Engine Pressures," AIAA Journal of Propulsion and Power, Vol. 10, No. 6, pp. 884-889, 1994.

${ }^{4}$ Cai, Z., and Steinetz, B.M., "Numerical Simulation of the Leakage Flow of Textile Engine Seals," presented at the 26th International SAMPE Technical Conference, Oct. 17-20, 1994, Atlanta, GA.

${ }^{5}$ Mutharasan, R., Steinetz, B.M., Tao, K., and Ko, F., "Development of Braided Rope Seals for Hypersonic Engine Applications: Flow Modeling," AIAA Journal of Propulsion and Power, Vol. 9, No. 3, May-June, 1993, pp. 456-461.

${ }^{6}$ Steinetz, B.M., Adams, M.L., Bartolotta, P.A., Darolia, R., and Olsen, A., "High Temperature Braided Rope Seals for Static Sealing Applications," NASA TM-107233 rev., July 1996.

${ }^{7}$ Doebelin, E.O., "Measurement Systems, Application and Design," McGraw Hill, New York, 1983.

${ }^{8}$ DellaCorte, C., and Steinetz, B.M., "Relative Sliding Durability of Candidate High Temperature Fiber Seal Materials," NASA TM-105806, 1992.

TABLE 1.-BRAIDED ROPE SEAL CONSTRUCTION MATRIX

\begin{tabular}{|c|c|c|c|c|c|c|c|c|c|c|c|c|}
\hline \multirow[t]{2}{*}{ Seal type } & \multirow{2}{*}{$\frac{\text { Size }}{\begin{array}{c}\text { Diameter, } \\
\text { in. }\end{array}}$} & \multicolumn{4}{|c|}{ Core $^{a}$} & \multicolumn{7}{|c|}{ Sheath ${ }^{c}$} \\
\hline & & Material & Denier & $\begin{array}{c}\text { Fiber } \\
\text { diameter, } \\
\text { in. }\end{array}$ & $\begin{array}{l}\text { Number } \\
\text { of yarns }\end{array}$ & Material & Denier & $\begin{array}{c}\text { Fiber } \\
\text { diameter, } \\
\text { in. }\end{array}$ & $\begin{array}{l}\text { Thick- } \\
\text { ness } \\
\text { (layers) }\end{array}$ & $\begin{array}{c}\text { Number } \\
\text { of } \\
\text { filament/ } \\
\text { tow }\end{array}$ & $\begin{array}{l}\text { Braid } \\
\text { angle }\end{array}$ & $\begin{array}{c}\text { Number } \\
\text { of } \\
\text { carriers }\end{array}$ \\
\hline $\begin{array}{l}\text { All-ceramic: } \\
\text { NTWAC-1 }\end{array}$ & 0.063 & NX550 & 700 & $3.2 \times 10^{-4}$ & 15 & NX550 & 700 & $32 \times 10^{-4}$ & double & 1 & 30 & 4,8 \\
\hline $\begin{array}{l}\text { Hybrid: } \\
\text { NTWHY-1 }\end{array}$ & 0.060 & NX550 & 700 & $3.2 \times 10^{-4}$ & 35 & HSI88 & 110 & $1.6 \times 10^{-3}$ & single & 10 & 46 & 12 \\
\hline NTWHY-3 & 0.124 & NX550 & 700 & $32 \times 10^{-4}$ & 154 & HS 188 & 110 & $1.6 \times 10^{-3}$ & single & 6 & 56 & 24 \\
\hline NTWHY-5 & 0.060 & NX550 & 700 & $3.2 \times 10^{-4}$ & 35 & HS 188 & 110 & $1.6 \times 10^{-3}$ & single & 4 & 58 & 24 \\
\hline
\end{tabular}

${ }^{a} \mathrm{NX550}=$ Nextel 550 fiber, $3 \mathrm{M}$ product, $73 \% \mathrm{Al}_{2} \mathrm{O}_{3} 27 \% \mathrm{SiO}_{2}$

${ }^{b} 1 \times 10^{-3}$ in. $=25 \mu \mathrm{m}$.

HS1 88 = Haynes 188 wire, Fort Wayne Metals product, 38\% Co $22 \% \mathrm{Cr}$. $14 \% \mathrm{~W} 3 \% \mathrm{Fe} 1.25 \% \mathrm{Mn} 0.5 \%$ Si $0.08 \% \mathrm{La} 0.015 \% \mathrm{~B}$ 0.05\%C. 
TABLE 2.-ALL-CERAMIC AND HYBRID SEAL FLOW (100 Psid and $1300^{\circ} \mathrm{F}$ except as noted, after scrubbing), RESIDUAL INTERFERENCE, CONTACT WIDTH, AND PRELOAD FOR SEVERAL LINEAR CRUSH CONDITIONS AND FOR SINGLE AND DOUBLE STAGE CONFIGURATIONS

\begin{tabular}{|c|c|c|c|c|c|c|c|}
\hline Seal type & $\begin{array}{l}\text { Diameter, } \\
\text { in. }\end{array}$ & $\begin{array}{l}\text { Linear } \\
\text { crush, } \\
\text { in. }\end{array}$ & $\begin{array}{l}\text { Number } \\
\text { of stages }\end{array}$ & $\begin{array}{l}\text { Preload, } \\
\text { psi }\end{array}$ & $\begin{array}{l}\text { Contact } \\
\text { width, } \\
\text { in. }\end{array}$ & $\begin{array}{c}\text { Residual } \\
\text { interference, } \\
\text { in. }\end{array}$ & $\begin{array}{c}\text { Flow, } \\
\text { (SCFM/in.) }\end{array}$ \\
\hline All-ceramic & 0.063 & 0.018 & 1 & 250 & 0.052 & 0.011 & 0.176 \\
\hline All-ceramic & 0.063 & 0.018 & 2 & 250 & 0.052 & 0.011 & 0.075 \\
\hline All-ceramic & 0.063 & 0.022 & 1 & 815 & 0.054 & 0.012 & 0.102 \\
\hline All-ceramic & 0.063 & 0.024 & 1 & N/A & N/A & N/A & 0.133 \\
\hline All-ceramic & 0.063 & 0.026 & 1 & 1210 & 0.067 & 0.011 & 0.114 \\
\hline $\begin{array}{l}\text { Hybrid, } 58^{\circ} \\
\text { braid angle }\end{array}$ & 0.060 & 0.014 & 1 & 1670 & 0.043 & 0.006 & 0.231 \\
\hline $\begin{array}{l}\text { Hybrid, } 58^{\circ} \\
\text { braid angle }\end{array}$ & 0.060 & 0.014 & 2 & 1670 & 0.043 & 0.006 & 0.181 \\
\hline $\begin{array}{l}\text { Hybrid, } 46^{\circ} \\
\text { braid angle }\end{array}$ & 0.060 & 0.014 & 1 & 250 & 0.043 & 0.006 & $0.40^{b}$ \\
\hline $\begin{array}{l}\text { Hybrid, } 58^{\circ} \\
\text { braid angle }\end{array}$ & 0.060 & 0.018 & 1 & 2880 & 0.056 & 0.006 & 0.112 \\
\hline $\begin{array}{l}\text { Hybrid, } 46^{\circ} \\
\text { braid angle }\end{array}$ & 0.060 & 0.018 & 1 & 500 & 0.053 & 0.008 & $0.202^{c}$ \\
\hline $\begin{array}{l}\text { Hybrid, } 58^{\circ} \\
\text { braid angle }\end{array}$ & 0.060 & 0.021 & 1 & N/A & N/A & $\mathrm{N} / \mathrm{A}$ & 0.109 \\
\hline
\end{tabular}

${ }^{\text {a }}$ Residual interference is defined as the distance the seal will spring back while maintaining a seal load of at least $1 \mathrm{lb}$ per inch of seal.

bFlow value was extrapolated from a linear approximation based on 2 to 10 psid flow data.

${ }^{\mathrm{c}}$ Flow data was collected at 95 psid, $1500^{\circ} \mathrm{F}$.

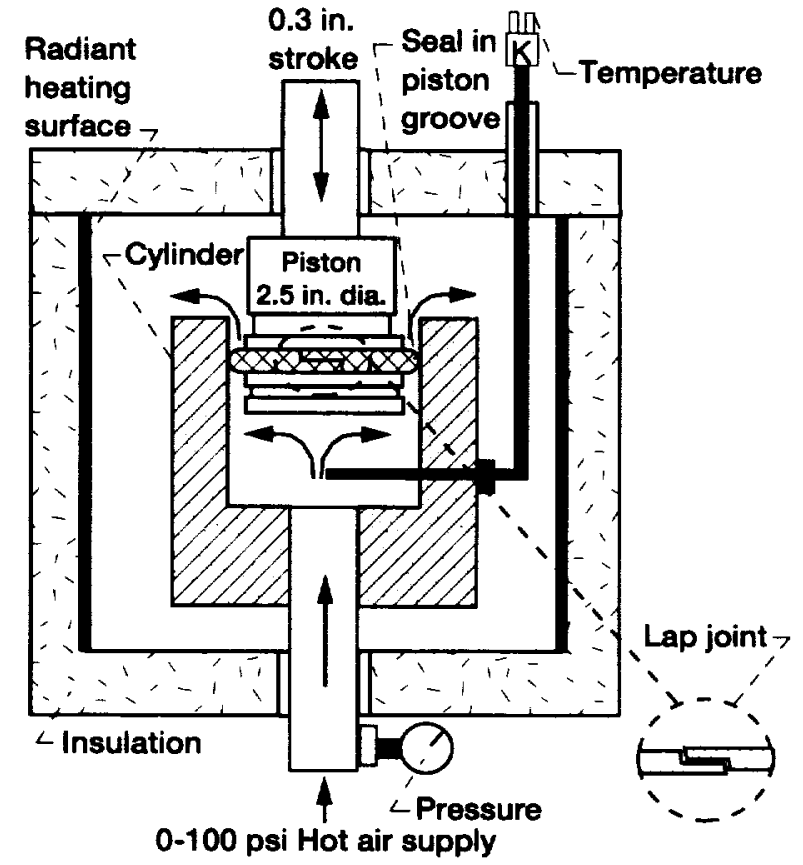

Figure 1. - Schematic of flow fixture.

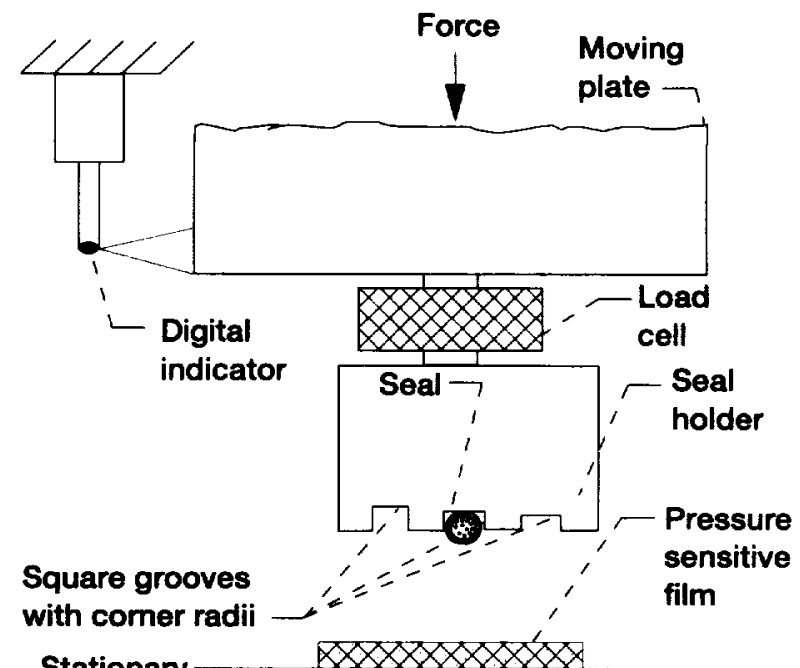

Stationary $x \times x \times x$ plate

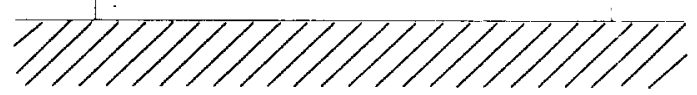

Figure 2.-Schematic of compression fixture. 

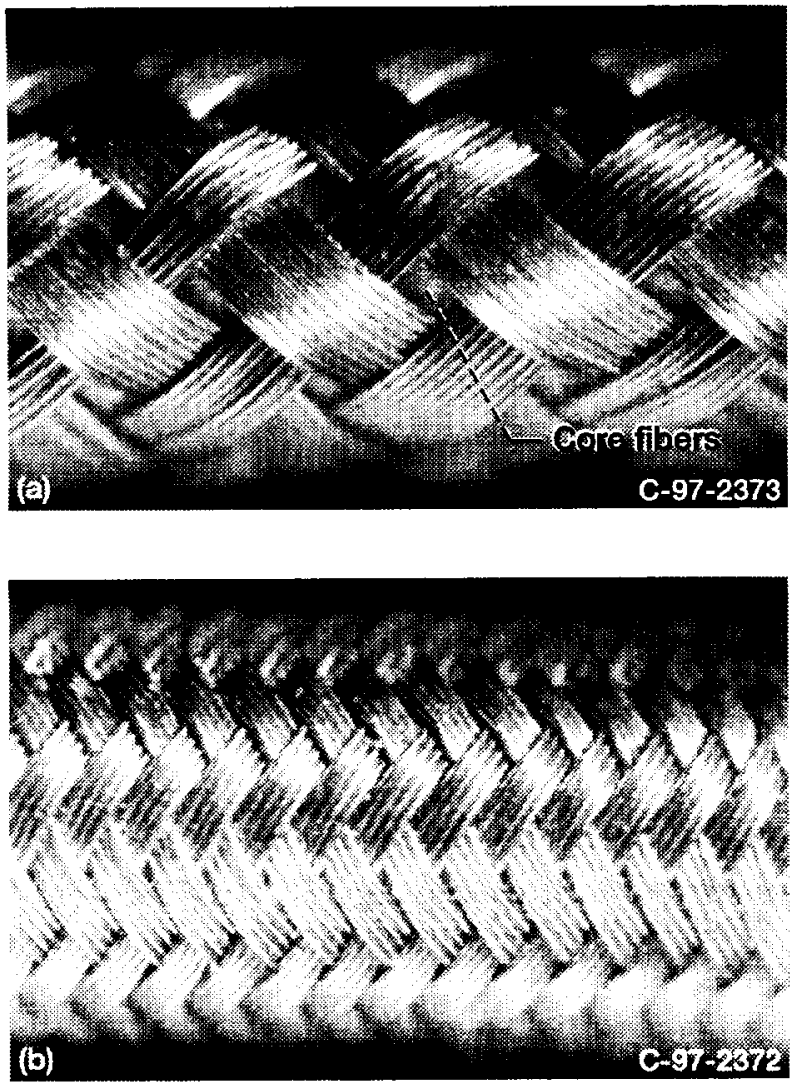

Figure 3.-Closeup photos of 1/16 in. hybrid seals (before scrubbing). (a) NTWHY $1 ; 10$ wires per bundle, $46^{\circ}$ braid angle. (b) NTWHY-5; 4 wires per bundle, $58^{\circ}$ braid angle.

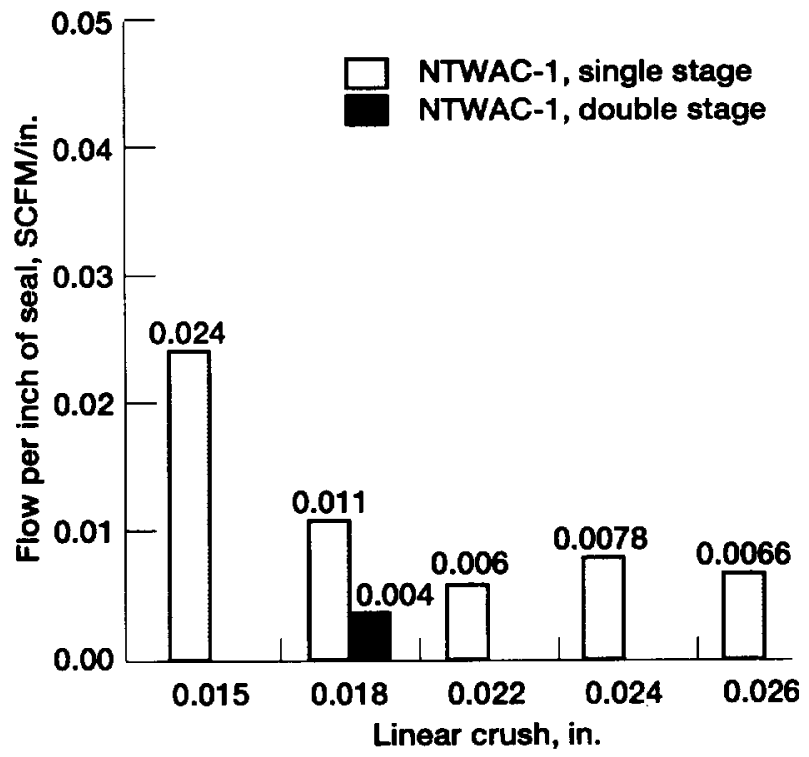

Figure 4.-The effect of seal compression and staging on seal flow for 1/16 in. diameter all-ceramic seals; after scrubbing, $\Delta p=10$ psid, $1300^{\circ} \mathrm{F}$.

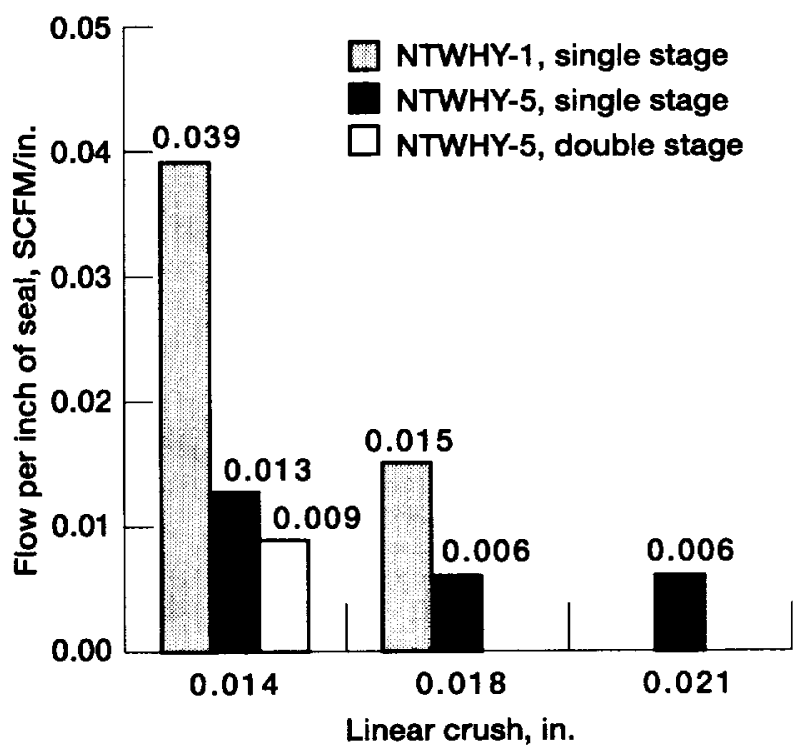

Figure 5.-The effect of seal compression, braid geometry and staging on seal flow for $1 / 16$ in. diameter hybrid seals; after scrubbing, $\Delta p=10 \mathrm{psid}, 1300^{\circ} \mathrm{F}$.

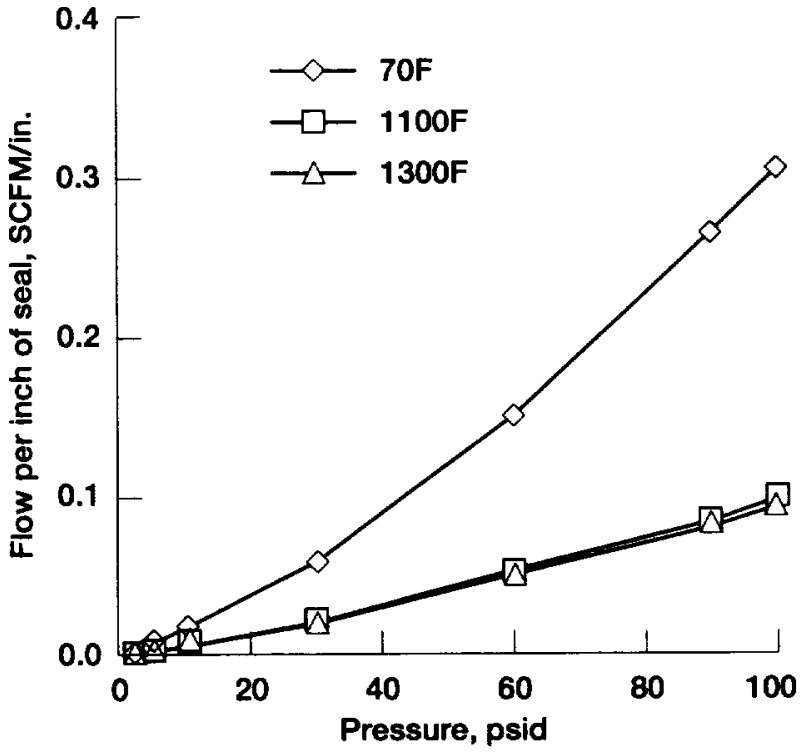

Figure 6.-Flow vs pressure data for 3 temperatures, 1/16 in. diameter all-ceramic seal (NTWAC-1), 0.022 in. seal compression, after scrubbing. 


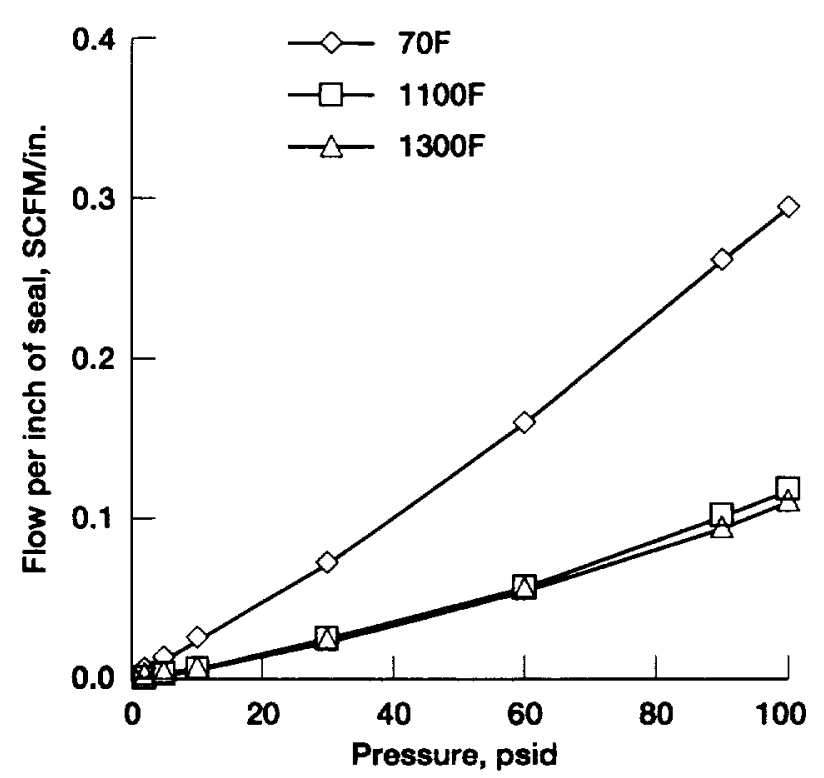

Figure 7.-Flow vs pressure data for 3 temperatures, $1 / 16$ in. diameter hybrid seal (NTWHY-5), 0.018 in. seal compression, after scrubbing.

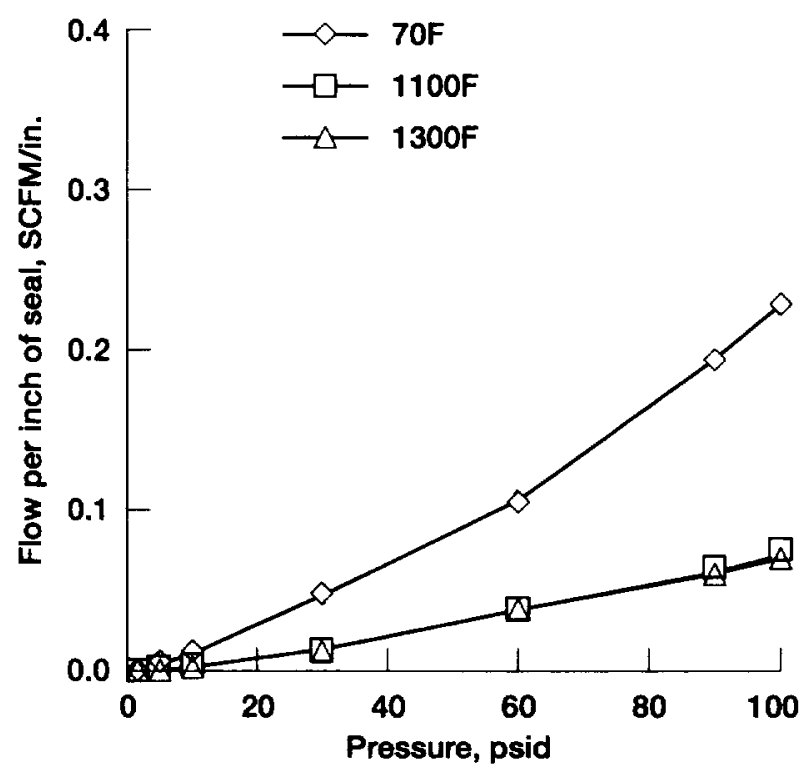

Figure 8.-Flow vs pressure data for 3 temperatures, 2 stages of 1/16 in. diameter all-ceramic seal, 0.018 in. seal compression, after scrubbing.

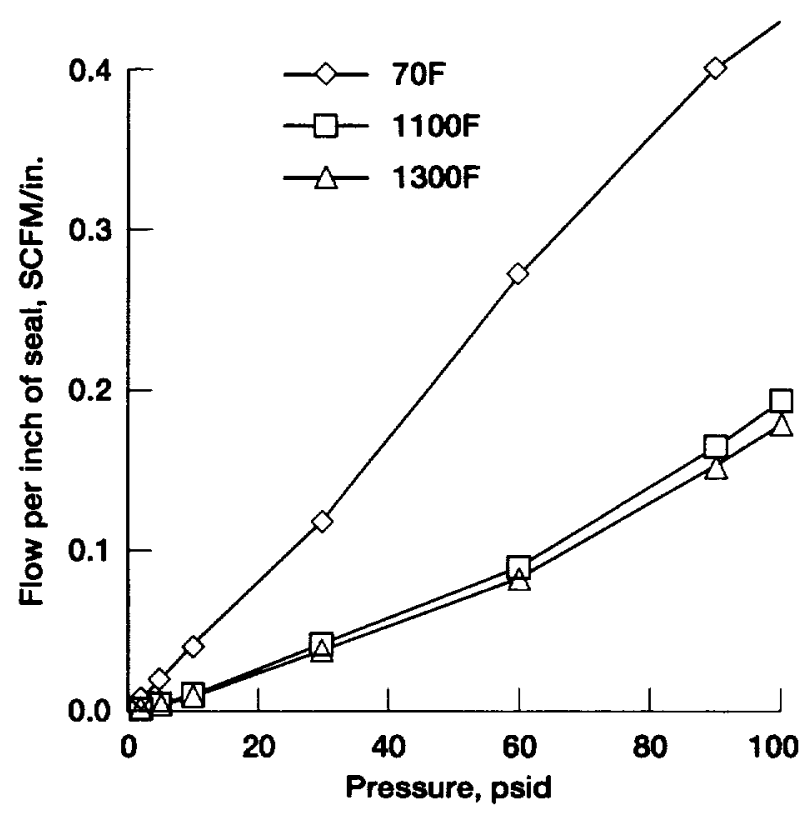

Figure 9.-Flow vs pressure data for 3 temperatures, 2 stages of 1/16 in. diameter, high braid angle hybrid seal, 0.014 in. seal compression, after scrubbing.

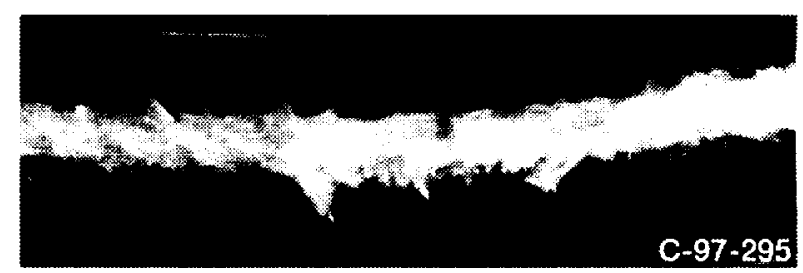

Figure 10.-Photo of 1/16 in. diameter all-ceramic seal after hot scrubbing, 0.022 in. linear seal compression.

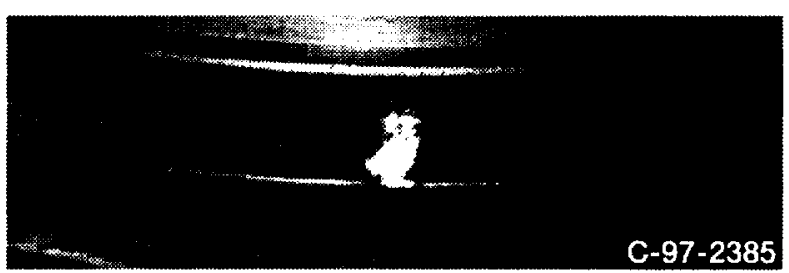

Figure 11.-Photo of 1/16 in. diameter hybrid seal after hot scrubbing, 0.014 in. linear seal compression (minor lap joint damage only). 


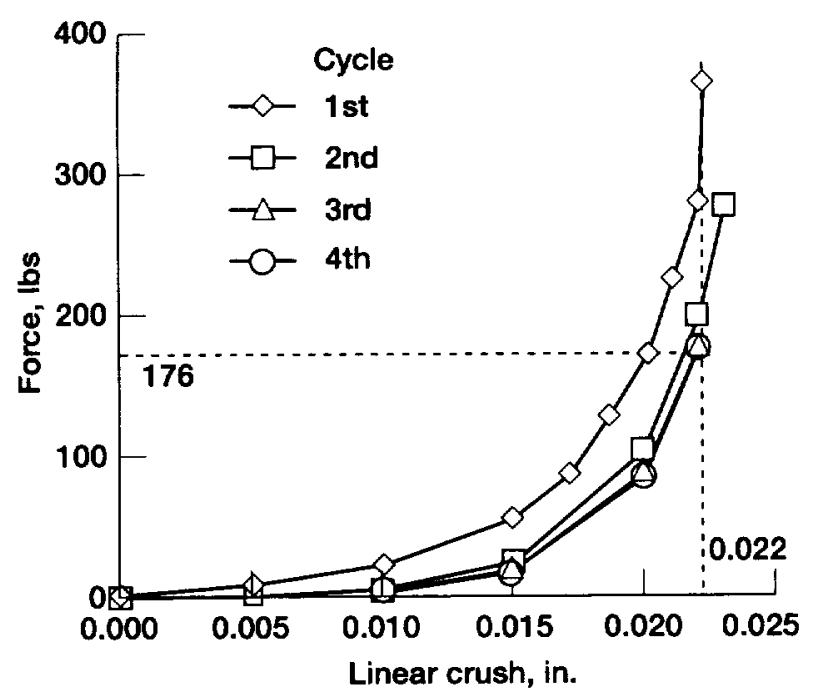

Figure 12.-Preload vs linear compression data, $1 / 16$ in. diameter all-ceramic seal, 815 psi preload.

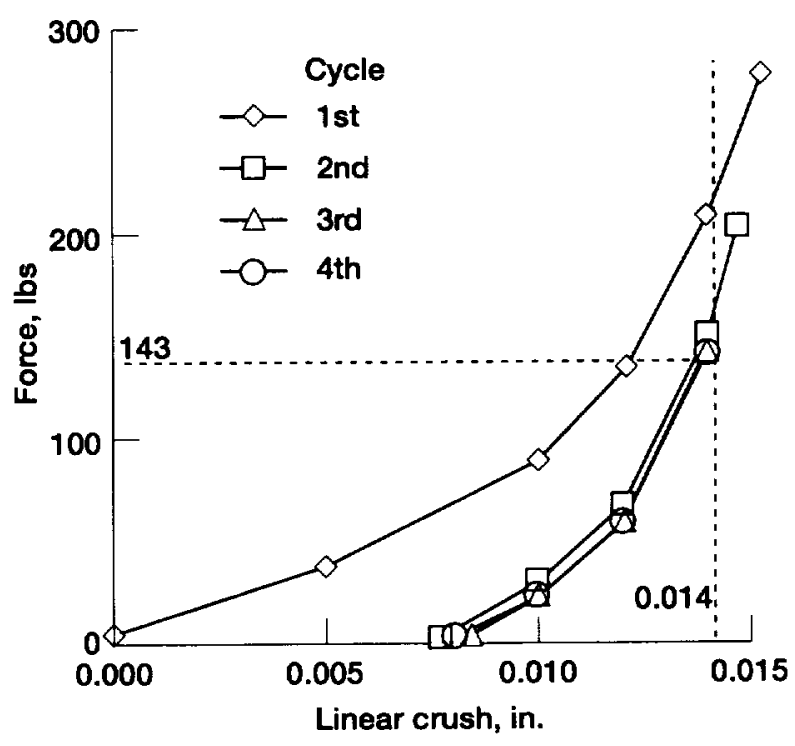

Figure 13.-Preload vs linear compression data, $1 / 16$ in. diameter, high braid angle hybrid seal, 1670 psi preload.

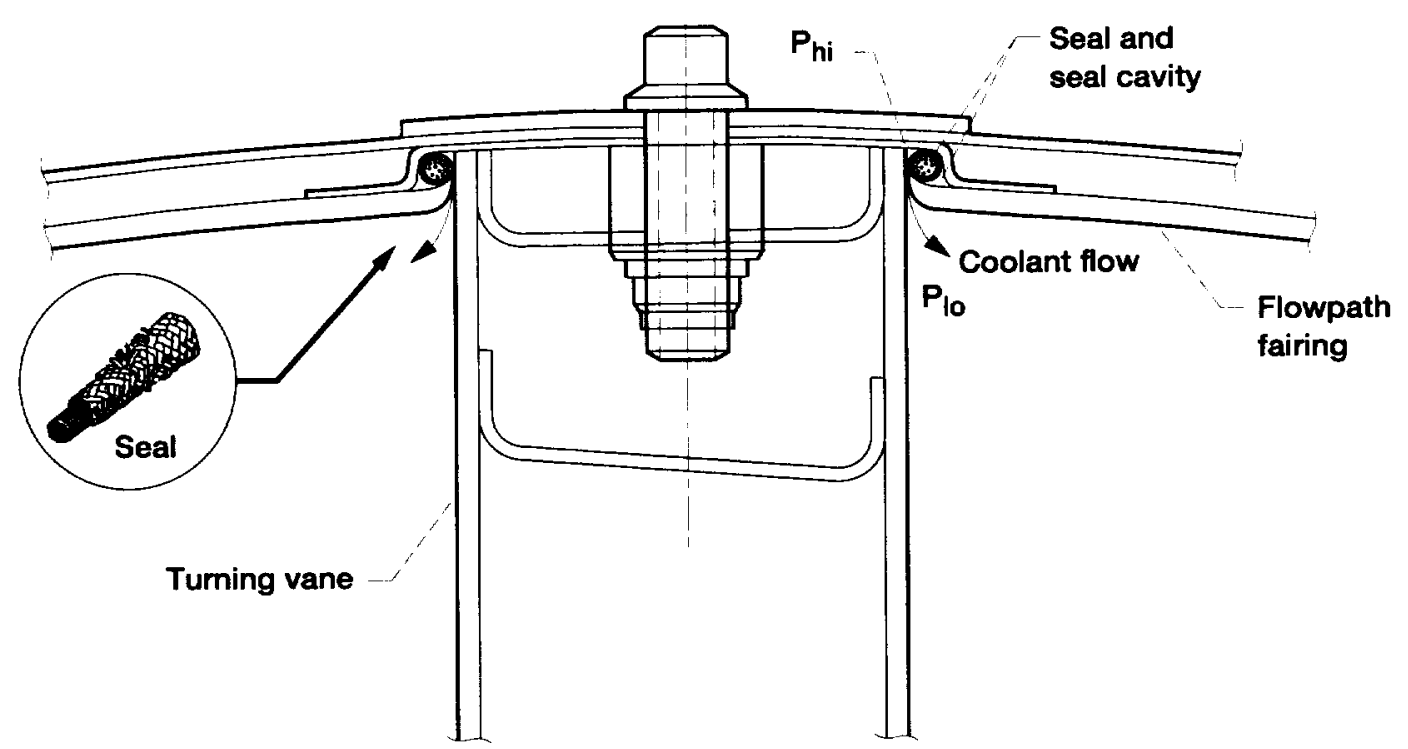

Figure 14.-Cross section of PW F119 engine last stage turning vane with hybrid seal sealing perimeter. 
Public reporting burden for this collection of information is estimated to average 1 hour per response, including the time for reviewing instructions, searching existing data sources, gathering and maintaining the data needed, and completing and reviewing the collection of information. Send comments regarding this burden estimate or any other aspect of this
collection of information, including suggestions for reducing this burden, to Washington Headquarters Senvices, Directorate for Information Operations and Repoorts, 1215 Jeflerson Davis Highway, Suite 1204, Artington, VA 22202-4302, and to the Office of Management and Budget, Paperwork Reduction Project (0704-0188), Washington, DC 20503.

\begin{tabular}{|c|c|c} 
1. AGENCY USE ONLY (Leave blank) & $\begin{array}{c}\text { 2. REPORT DATE } \\
\text { July } 1997\end{array}$ & $\begin{array}{r}\text { 3. REPORT TYPE AND DATES COVERED } \\
\text { Technical Memorandum }\end{array}$ \\
\hline
\end{tabular}

4. TITLE AND SUBTITLE

5. FUNDING NUMBERS

Effects of Compression, Staging, and Braid Angle on Braided

Rope Seal Performance

\section{AUTHOR(S)}

Bruce M. Steinetz and Michael L. Adams

7. PERFORMING ORGANIZATION NAME(S) AND ADDRESS(ES)

National Aeronautics and Space Administration

Lewis Research Center

Cleveland, Ohio 44135-3191

WU-505-23-2L

9. SPONSORING/MONITORING AGENCY NAME(S) AND ADDRESS(ES)

10. SPONSORINGMONITORING AGENCY REPORT NUMBER

National Aeronautics and Space Administration

Washington, DC 20546-0001

NASA TM-107504

AIAA-97-2872

11. SUPPLEMENTARY NOTES

Prepared for the 33rd Joint Propulsion Conference and Exhibit cosponsored by AIAA, ASME, SAE, and ASEE, Seattle, Washington, July 6-9, 1997. Bruce Steinetz, NASA Lewis Research Center and Michael L. Adams, Modern Technologies Corporation, 7530 Lucerne Drive, Islander Two, Suite 206, Middleburg Heights, Ohio 44130. Responsible person, Bruce Steinetz, organization code 5950, (216) 433-3302.

12a. DISTRIBUTION/AVAILABILITY STATEMENT

Unclassified - Unlimited

Subject Category 37

This publication is available from the NASA Center for AeroSpace Information, (301) $621-0390$.

13. ABSTRACT (Maximum 200 words)

Future turbine engines and industrial systems will be operating at increased temperatures to achieve more demanding efficiency and performance goals. In the highest temperature sections of the engine new material systems such as ceramics and intermetallics are being considered to withstand the harsh thermal environment. Components constructed of these low expansion-rate materials experience thermal strains and a resulting reduction of life when rigidly attached to high expansion-rate, superalloy support structures. Seals are being designed to both seal and to serve as compliant mounts allowing for relative thermal growths between high temperature but brittle primary structures and the surrounding support structures. Previous seal research yielded several braided rope seal designs which demonstrated the ability to both seal and serve as a compliant mount. The hybrid seal was constructed of an all-ceramic (alumina-silica) core overbraided with a superalloy wire sheath (cobalt based superalloy). The all ceramic seal was constructed of an all-ceramic (alumina-silica) core overbraided with multiple ceramic (aluminasilica) sheath layers. Program goals for braided rope seals are to improve flow resistance and/or seal resilience. To that end, the current report studies the test results of: baseline and modified hybrid seals; two stage hybrid and two stage all-ceramic seal configurations; and single stage hybrid and single stage all-ceramic seal configurations for a range of seal crush conditions. Hybrid seal modifications include increasing the sheath braid angle and core coverage. For the same percent seal cross-sectional crush, results show that increasing the hybrid seal braid angle increased seal stiffness and seal unit load, resulting in flows approximately one third of the baseline hybrid seal flows. For both hybrid and allceramic seals, two stage seal configurations significantly outperformed single stage configurations. Two stage seal flows were at least $30 \%$ less than the single stage seal flows for the same seal crush. Furthermore, test results of single stage seals indicate that for both all-ceramic and hybrid seals, a specific seal crush condition exists at which minimum flows are achieved (i.e. increasing seal crush beyond a certain point does not result in better flow performance). Flow results are presented for a range of pressures and temperatures from ambient to $1300^{\circ} \mathrm{F}$. before and after scrubbing. Compression tests results show that for both all-ceramic and hybrid seals, seal preload and stiffness increase with seal crush, but residual seal interference remains constant.

14. SUBJECT TERMS

Seal; Braid; Flow; Preload; Turbine engine

15. NUMBER OF PAGES

00

16. PRICE CODE

$\mathrm{A} 00$

\begin{tabular}{|c|c|c|}
\hline $\begin{array}{c}\text { 17. SECURTY CLASSIFICATION } \\
\text { OF REPORT } \\
\text { Unclassified }\end{array}$ & $\begin{array}{c}\text { 18. SECURITY CLASSIFICATION } \\
\text { OF THIS PAGE } \\
\text { Unclassified }\end{array}$ & $\begin{array}{c}\text { 19. SECURITY CLASSIFICATION } \\
\text { OF ABSTRACT } \\
\text { Unclassified }\end{array}$ \\
\hline
\end{tabular}

NSN 7540-01-280-5500 